\begin{tabular}{c|cc}
$\begin{array}{c}\text { ADVANCE RESEARCH JOURNAL OF SOCIAL SCIENCE } \\
\text { ARTICLE }\end{array}$ & $\begin{array}{c}\text { Rolume } 7 \mid \text { Issue } 2 \mid \text { December, 2016 | 270-274 } \\
\text { a ISSN-2231-6418 }\end{array}$ \\
DOI: 10.15740/HAS/ARJSS/7.2/270-274 & visit us : www.researchjournal.co.in
\end{tabular}

\title{
Socio-economic profile of women entrepreneurs
}

Seemaprakalpa

Department of Home Science Extension Education, Institute of Home Science, Dr. B.R. Ambedkar University, AGRA(U.P.) INDIA (Email: prakalpass@gmail.com)

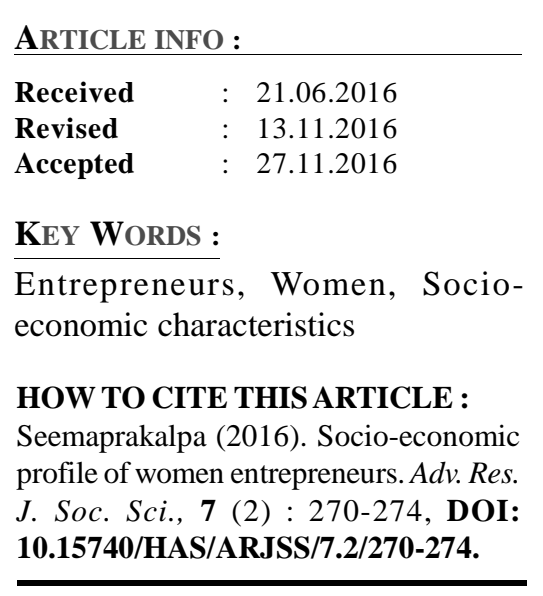

\begin{abstract}
Government is providing many facilities to upgrade the socio-economic status of women entrepreneurs which required further research. The present study was conducted to analyze the socio-economic background of women entrepreneurs. The socio-economic characteristics were studied under three heads; personal, family, and enterprise related characteristics. Primary data were collected through interview schedule in zones of Agra city in U.P. during 2002-2005 and percentage was used as a statistical measure. The study shows that the majority of entrepreneurs were in the middle age group $(45 \%)$, belonging to general category $(81.70 \%)$, graduate and above (75\%), married (78.30\%), belonging to nuclear $(76.70 \%)$; medium-sized (70\%), business families $(75 \%)$ having an income below mean per capita per annum $(56.70 \%)$.
\end{abstract}

